\title{
Pengembangan Perangkat Pembelajaran Terpadu Tipe Shared Berbasis Saintifik Untuk Meningkatkan Hasil Belajar Di SD
}

\author{
Linaria Arofatul Ilmi Uswatun Khasanah \\ Universitas Muhammadiyah Lamongan, Lamongan, Indonesia \\ *Corresponding author: linaria.aiuk11@gmail.com
}

\begin{abstract}
This research is based on the lack of knowledge of teachers to develop learning tools and formulate the integration of each subject so that it affects the low student learning outcomes. The objectives of this study were to discover the feasibility, practicality and effectiveness of integrated learning tools type shared based on scientific approaches that can improve the learning results of fourth grade students in elementary schools. The development procedure in this research was applied the Dick and Carey method and was carried out by trials. Product design were consisting of expert trials, individual trials, small group trials, and large trials. Data collection techniques was collected from student responses and pretest-posttest results as well as test analysis with validity, normality, homogeneity and t test. The results of this study showed the normality test between the experimental and control groups in the pre-test and post-test with a normal distribution of significance $>0.05$ and data was stated homogeneous because the significance value is $0.886>0.05$ it showed that there was an influence between the use of scientific-based integrated learning media type shared in improving the learning results of fourth grade student Elementary School
\end{abstract}

Keywords: integrated learning media type shared; scientific; student learning result

\begin{abstract}
ABSTRAK
Penelitian ini dilatarbelakangi pada kurangnya pengetahuan guru untuk mengembangkan perangkat pembelajaran serta merumuskan keterpaduan setiap mata pelajaran sehingga berpengaruh terhadap rendahnya hasil belajar siswa. Tujuan penelitian ini adalah untuk mengetahui kelayakan, kepraktisan dan keefektifan perangkat pembelajaran terpadu berbasis pendekatan saintifik yang dapat meningkatkan hasil belajar siswa kelas IV sekolah dasar. Prosedur pengembangan dalam penelitian ini menerapkan metode Dick and Carey dan dilakukan melalui uji coba. Perancangan produk terdiri dari uji ahli, uji coba individu, uji coba kelompok kecil, dan uji coba besar. Teknik pengumpulan data diperoleh dari respon siswa dan hasil pretes-postes serta uji analisis dengan uji validitas, normalitas, homogenitas dan uji t. Hasil penelitian menunjukkan uji normalitas antara kelompok eksperimen dan kontrol pada pre-test dan post-test dengan distribusi normal signifikansi> 0,05 dan data dinyatakan homogen karena nilai signifikansi 0,886> 0,05 menunjukkan adanya Ada pengaruh antara penggunaan media pembelajaran terpadu berbasis saintifik dalam meningkatkan hasil belajar siswa kelas IV Sekolah Dasar.
\end{abstract}

Kata Kunci: hasil belajar; perangkat pembelajaran; saintifik; tipe shared

\section{Pendahuluan}

Kurikulum 2013 di Sekolah Dasar melaksanakan pembelajaran terpadu dan prosesnya menerapkan pendekatan saintifik. Proses pembelajaran pada satuan pendidikan diselenggarakan secara interakatif, inspiratif, menyenangkan, menantang, memotivasi peserta didik untuk berpartisipasi aktif, serta memberikan ruang yang cukup bagi prakarsa, kreativitas, dan kemandirian sesuai dengan bakat, minat dan perkembangan fisik serta psikologis peserta didik. Menurut Trianto (2012:7) melalui pembelajaran terpadu peserta didik 
dapat memperoleh pengalaman langsung sehingga dapat menambah kekuatan untuk menerima, menyimpan, dan menerapkan konsep yang dipelajarinya.

Berdasarkan wawancara yang telah dilakukan oleh peneliti kepada guru kelas bahwa dalam proses mengajar guru tidak menggunakan kegiatan $5 \mathrm{M}$ yaitu (mengamati, menanya, menalar, mencoba, mengkomunikasikan) dalam satu semester guru hanya mengajar dengan menggunakan kegiatan mengamati dan menanya saja sehingga pemahaman siswa hanya berpatok pada kedua kegiatan tersebut yang seharusnya ke limanya harus ada dalam satu semester. Kegiatan mengajar pada pembelajaran tematik yang seharusnya mengamit tahapan pembelajaran saintifik yakni mengamati, menanya, mengasosiasi, mencoba, serta membentuk jejaring dalam setiap pelaksanaan pembelajarannya yang terbagi pada tema. Pada 1 tema dibagi menjadi sub tema serta setiap sub tema dibagi menjadi 6 pembelajaran, namun yang menjadi masalahnya adalah bagaimana melaksanakan pembelajaran dari beberapa mata pelajaran yang disajikan dalam satu pembelajaran agar tidak terlihat perpindahan mata pelajaran satu ke mata pelajaran lainnya.

Selain itu, pembelajaran tematik di SD Tunjung Mekar ditemukan beberapa permasalahan diataranya (1) guru merasa terhambat pada saat merumuskan keterpaduan dari setiap mata pelajaran pada tahapan pembelajaran (2) Materi pembelajaran yang sudah ada masih memakai pendekatan mata pelajaran jadi menyusahkan guru dalam menyatukan materi sesuai tema (3) guru terhambat ketika mengembangkan tema serta contoh tema tidak sama seperti kondisi lingkungan belajar (4) guru masih kurang faham dengan Kurikulum 2013, sehingga guru masih merasa kebingungan dalam menerapkan Kurikulum 2013 (5) dalam proses pembelajaran guru masih membutuhkan contoh-contoh perangkat pembelajaran yang sesuai dengan tuntutan dalam Kurikulum 2013 karena dalam sekolah guru hanya berpatok pada buku guru dan buku siswa, sehingga guru merasa bahwa hasil yang didapatkan masih belum optimal. (6) kurangnya pengetahuan guru untuk mengembangkan perangkat pembelajaran.

Kurikulum 2013 memiliki 10 tipe yang setiap tipenya memiliki ciri khas tersendiri, salah satunya tipe shared yang menggabungkan dua mata pelajaran dengan melihat konsep, sikap dan keterampilan yang sama dan saling berhubungan satu dengan yang lain. melalui penggabungan disiplin ilmu serupa yang saling tumpang tindih akan memungkinkan peserta didik mempelajari konsep yang lebih mendalam dari kedua mata pelajaran tersebut serta dapat menciptakan pengalaman belajar siswa dengan meletakkan kegiatan mereka bersama sehingga waktu yang digunakan dapat lebih lama dengan menggunakan pendekatan saintifik. Majid (2014:193) berpendapat dalam menerapkan pendekatan saintifik memiliki tujuan agar mampu memberikan pemahaman kepada siswa seperti mengenal dan mengerti macammacam materi dengan memakai pendekatan saintifik. Bahwa infromasi bisa diperoleh darimana saja, kapan saja, dan juga siapa jaga, bukan hanya informasi yang disampaikan oleh guru saja.

Hasil observasi di kelas IV SDN Tunjung Mekar pada kurikulum 2013 tema "Indahnya Keragaman di Negeriku" diperoleh nilai yang masih di bawah kriteria ketentuan minimum (KKM) yaitu 75. Kurangnya persiapan guru dalam mengajar sangat berpengaruh pada hasil belajar siswa, terlihat banyak siswa mendapatkan nilai di bawah KKM. Menurut Budi dkk (2020) Hasil belajar merupakan kemampuan-kemampuan yang dimiliki siswa setelah ia 
menerima pengalaman belajar baik itu berupa pembentukan tingkah laku maupun perbuatan. Pada penelitian ini, hasil belajar siswa akan mengarah pada tiga ranah yakin kognitif, afektif dan juga psikomotor.

Berdasarkan permasalahan di atas maka tujuan penelitian ini adalah : (1) mendeskripsikan kelayakan perangkat pembelajaran terpadu tipe shared berbasis pendekatan saintifik untuk meningkatkan hasil belajar siswa kelas IV di Sekolah Dasar (2) mendeskripsikan kepraktisan perangkat pembelajaran terpadu tipe shared berbasis pendekatan saintifik untuk meningkatkan hasil belajar siswa kelas IV di Sekolah Dasar (3) mendeskripsikan keefektifan perangkat pembelajaran terpadu tipe shared berbasis pendekatan saintifik untuk meningkatkan hasil belajar siswa kelas IV di Sekolah Dasar.

Prabowo (2000:3) mengatakan bahwa pembelajaran terpadu sebagai suatu proses mempunyai beberapa ciri yaitu: (1) berpusat pada siswa (student centered), (2) proses pembelajaran mengutamakan pemberian pengalaman langsung, dan (3) pemisahan antar bidang studi tidak terlihat jelas. Dalam pembelajaran terpadu tipe Shared didasarkan pada ideide pembagian yang berasal dari dalam ilmu tersebut. Sri Anitah (2003:10) pembelajaran terpadu adalah sebagai suatu konsep-konsep secara terkoneksi baik inter maupun antar mata pelajaran. Terjalinnya hubungan antar setiap konsep secara terpadu akan memfasilitasi siswa untuk aktif dalam proses pembelajaran dan mendorong siswa untuk memahami konsepkonsep yang mereka pelajari melalui pengalaman langsung dan menghubungkannya dengan pengalaman nyata.

Dalam pelaksanaannya langkah-langkah pembelajaran terpadu sama seperti model pembelajaran yang lain, meliputi tahap perencanaan, tahap pelaksanaan, dan tahap evaluasi. Berkaitan dengan tersebut maka sintak model pembelajaran terpadu dapat direduksi dari berbagai model pembelajaran. Dengan demikian sintaks pembelajaran terpadu dapat bersifat luwes dan fleksibel. Artinya, sintaks dalam pembelajaran terpadu dapat diakomodasikan dari berbagai model pembelajaran. (Dewi:2013).

Pembelajaran terpadu tipe shared dikemukakan oleh Robin Fogarty, tipe ini mengarahkan guru dalam proses pembelajaran menggunakan dua mata pelajaran digabungkan menjadi satu. Pada tipe ini tema yang memayungi dua mata pelajaran, dimana aspek kognitif, keterampilan dan sikap menjadi satu kesatuan yang utuh. (Fogarty, 1991:44).

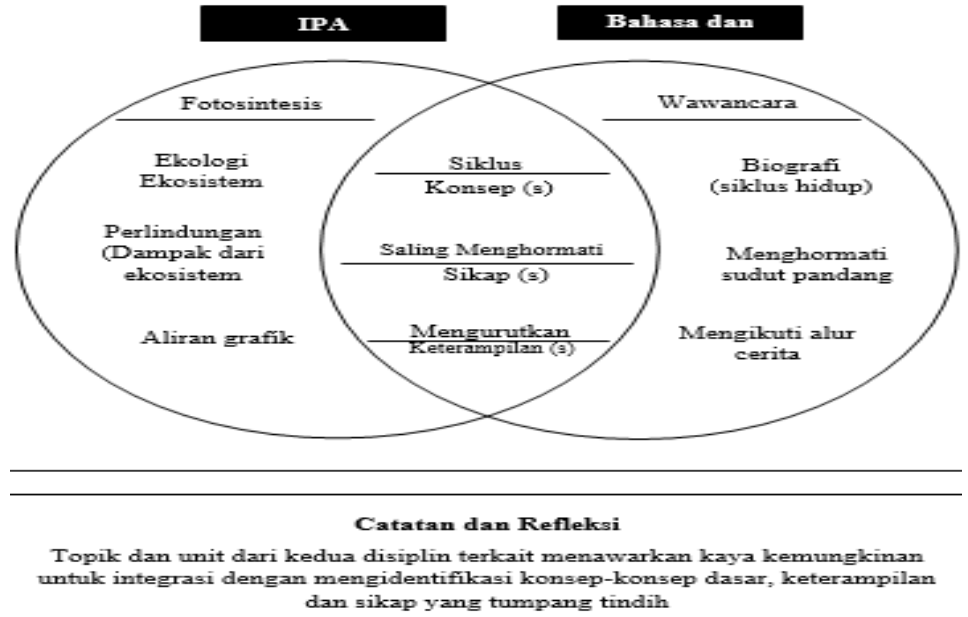

Gambar 1. Pemetaan Pembelajaran Terpadu Tipe Shared (Fogarty, 1991:48) 
Kelebihan dari model terbagi ini terletak pada kemudahan dalam penggunaannya sebagai langkah awal menuju model terintegrasi sepenuhnya yang menekankan pencakupan empat bidang studi utama. Dengan menggabungkan disiplin yang sejenis, maka kesamaan tema akan memfasilitasi pembelajaran yang lebih mendalam tentang konsep-konsep yang diajarkan. Hal ini berdasarkan penelitian Surahman (2013) kegiatan pembelajaran dengan model IPA terpadu tipe shared dalam kegiatan pembelajaran memiliki karakteristik "holistik" yang terkesan memotivasi mereka dengan materi yang erat dengan kehidupan sehari-hari siswa. sehingga hasil penelitian menunjukkan kelayakan perangkat pembelajaran terpadu tipe shared sangat layak dan instrumen tes hasil belajar dengan validitas sangat tinggi.

Dalam penelitian sebelumnya, pengembangan perangkat pembelajaran terpadu tipe shared masih belum menggunakan pendekatan saintifik, sehingga pada penelitian ini akan dilaksanakan dengan menggunakan pendekatan saintifik dalam kegiatan pembelajaran. Menurut Utami (2019) Pengembangan perangkat pembelajaran dengan pendekatan saintifik tentunya membantu baik guru maupun siswa untuk mampu mencapai tujuan belajar dan membuat proses pembelajaran lebih bermakna bukan hanya sekedar menghapal.

Kemendikbud 2013 (dalam Atsnan, 2013:430) kegiatan pembelajaran saintifik ialah paduan antara kegiatan pembelajaran yang awalnya berfokus pada eksplorasi, elaborasi, dan konfirmasi dilengkapi dengan mengamati, menanya, menalar, mencoba, dan mengkomunikasikan. Pembelajaran dengan menggunakan pendekatan saintifik mengacu pada pendekatan ilmiah, pendekatan ilmiah berupaya untuk membangun untuk menarik minat anak, pendekatan ilmiah mampu menarik kreativitas, imajinasi dan ide. (Yunita:2019).

\section{Metode Penelitian}

Penelitian ini termasuk penelitian pengembangan, perangkat pembelajaran yang akan dikembangkan adalah silabus, RPP, materi ajar, lembar kerja peserta didik dan tes hasil belajar. Penelitian serta pengembangan merupakan metode penelitian yang berfungsi untuk mendapatkan produk tertentu, serta menguji keefektifan produk tersebut. (Sugiono, 2011:297). Subjek penelitian ini adalah siswa kelas IV SDN Tunjung Mekar. Pertimbangan dalam memilih SDN Tunjung Mekar adalah karena pada sekolah ini sebelumnya belum pernah ada penelitian tentang pengembangan perangkat pembelajaran terpadu tipe shared berbasis saintifik untuk meningkatkan hasil belajar siswa kelas IV di SDN Tunjung Mekar.

Prosedur pengembangan berisi tahap-tahap yang dilakukan dalam setiap pengembangan yang dilakukan (Mega, 2020). Prosedur pengembangan pada penelitian ini menggunakan model pengembangan Dick and Carey. Strategi dan desain pembelajaran menurut Dick and Carey (1985) adalah bahan pembelajaran yang akan digunakan dalam mengajar untuk menghasilkan hasil tertentu. langkah-langkah model pengembangan di uraikan sebagai berikut :

1. Mengidentifikasi tujuan umum pembelajaran (Identify intructional analysis).

Pada tahapan ini bertujuan untuk mengumpulkan informasi serta mengidentifikasi permasalahan yang mendasar yang dihadapi oleh guru kelas, hasil tersebut menjadi acuan untuk mengembangkan perangkat pembelajaran agar lebih terarah dan mampu menghasilkan produk sesuai dengan yang dibutuhkan.

2. Melakukan analisis pembelajaran 
Langkah yang dilakukan dalam analisis pembelajaran adalah menentukan pengetahuan, sikap, serta keterampilan yang akan diperoleh peserta didik setelah menggunakan perangkat pembelajaran terpadu tipe shared berbasis saintifik.

3. Menganalisis Siswa dan Konteks Pembelajaran (Analyze Learner and Context)

Menganalisis siswa bertujun untuk mengidentifikasi kemampuan awal peserta didik yang dapat dijadikan pedoman ketika memilih menentukan strategi pembelajaran yang digunakan. Sedangkan analisis konteks meliputi keterampilan peseta didik yang ada di dalam kelas bermacam-macam (heterogen), sehingga guru harus bisa membawa semua peserta didik baik yang mempunyai kemampuan tinggi maupun kemampuan yang rendah agar dapat memahami materi pelajaran atau mencapai tujuan pembelajaran secara bersama-sama.

4. Merumuskan Tujuan Khusus Pembelajaran (Write Performance Objectives)

Kemampuan dan perilaku dapat dirumuskan secara spesifik sehingga dapat diamati dan di ukur ketercapaiannya dengan menggunakan tes dan alat ukur lainnya.

5. Mengembangkan Instrumen Penilaian (Develop Assesment Instrument)

Instrumen penilaian digunakan dalam penelitian pengembangan ini berupa pretest dan posttest, penilaian hasil belajar siswa.

6. Mengembangkan Strategi Pembelajaran (Develop Instructional Strategy)

Tujuan pembelajaran ini untuk meningkatkan hasil belajar siswa melalui perangkat pembelajaran terpadu tipe Shared berbasis saintifik.

7. Memilih dan Mengembangkan Bahan Pembelajaran (Develop and Select Instryctional Materials)

Pada tahapan ini adalah mengembangkan bahan ajar yang disesuaikan dengan hasil analisis dan observasi di lapangan. Materi yang akan dikembangkan disesuaikan dengan pendekatan saintifik yang di dalamnya mencakup kegiatan mengamati, menanya, menyampaikan informasi, mengorganisasikan serta mengomunikasikan.

8. Merancang serta Melaksanakan Evluasi Formatif Pembelajaran

Dick \& Carey merekomendasikan suatu proses evaluasi formatif yang terdiri atas tiga langkah, yaitu:

a. Uji coba secara perorangan dilakukan terhadap tiga siswa

b. Uji coba kelompok kecil yang terdiri atas enam atau tujuh subjek

c. Uji coba lapangan yaitu seluruh siswa yang ada kelas

9. Revisi Pembelajaran (Revise Instruction)

Melalui kegiatan revisi pengembang melakukan revisi terhadap draft perangkat pembelajaran terpadu tipe shared berbasis saintifik. Data yang diperoleh akan di analisis serta dirangkum untuk mengetahui kelemahan-kelemahan pada setiap aspek kemudian akan di perbaiki dan disempurnakan untuk mencapai tujuan pembelajaran.

Subjek penelitian ini dilakukan pada siswa kelas IV di SDN Tunjung Mekar Kalitengah Lamongan sebanyak 26 siswa menjadi kelas eksperimen serta siswa kelas IV SDN Pengangsalan 2 kelas sebanyak 26 siswa sebagai kelas control. Instrumen penelitian yang digunakan dalam penelitian ini adalah sebagai berikut:

1. Lembar Validasi

2. Lembar Pengamatan meliputi keterlaksanaan program,keaktifan siswa dang angket siswa

3. Tes Hasil Belajar yang terdiri dari pree test dan post test. 
Alat analisis yang digunakan adalah uji validitas ,uji homogenitas dan uji t.dimana uji ini mencakup semua hasil angket siswa baik dari kelompok control maupun kelompok eksperimen.data dari hasil tes post test maupun pree test.

\section{Hasil dan Pembahasan}

Perangkat pembelajaran yang telah dikembangkan dalam penelitian ini adalah perangkat pebelajaran terpadu tipe shared yang di kembangkan terdiri dari silabus, RPP, lembar kerja peserta didik, dan tes hasil.

1. Hasil Validasi Kelayakan Perangkat

Hasil dari penilaian validator pertama yaitu secara umum sudah baik namun terdapat beberapa yang perlu di perbaiki mulai dari penulisan karena terdapat beberapa penulisan yang salah ketik. Untuk validator kedua terdapat beberapa masukan seperti penggunaan huruf lebih tegas di dalam bahan ajar agar lebih mudah di pahami. Secara umum perangkat pembelajaran yang dikembangkan sudah di revisi sesuai dengan masukan yang diberikan oleh validator.

a. hasil validasi silabus menunjukkan bahwa hasil yang didapatkan dari validator I sebesar 94\%. Validator II memperoleh total skor sebesar 52 dengan persentase $100 \%$. Kedua skor tersebut di total berjumlah 101 dengan rata-rata 51 dengan persentase $97 \%$ dari hasil presentase tersebut dapat dikatakan bahwa silabus sangat valid/dapat digunakan dengan kriteria perangkat pembelajaran $>85,01 \%$ menurut intepretasi skla likert perangkat dapat digunakan tanpa revisi.

b. hasil validasi Rencana Pelaksaan Pembelajaran (RPP) menunjukkan bahwa hasil yang didapatkan dari validator I memperoleh total skor sebesar 84 dengan persentase 95\%. Validator II memperoleh total skor sebesar 85 dengan persentase $96 \%$. Kedua skor tersebut di total berjumlah 169 dengan rata-rata 84 dengan persentase $96 \%$ dari hasil presentase tersebut dapat dikatakan bahwa Rencana Pelaksanaan Pembelajaran (RPP) sangat valid/dapat digunakan dengan kriteria perangkat pembelajaran $>85,01 \%$ menurut intepretasi skala likert.

c. hasil validasi materi pembelajaran menunjukkan bahwa hasil yang didapatkan dari validator I memperoleh total skor sebesar 54 dengan persentase $90 \%$. Validator II memperoleh total skor sebesar 60 dengan persentase 100\%. Kedua skor tersebut di total berjumlah 114 dengan rata-rata 57 dengan persentase 95\% dari hasil presentase tersebut dapat dikatakan bahwa materi pembelajaran sangat valid/dapat digunakan dengan kriteria perangkat pembelajaran $>85,01 \%$.

d. hasil validasi materi pembelajaran menunjukkan bahwa hasil yang didapatkan dari validator I memperoleh total skor sebesar 57 dengan persentase $89 \%$. Validator II memperoleh total skor sebesar 60 dengan persentase $94 \%$. Kedua skor tersebut di total berjumlah 117 dengan rata-rata 58,5 dengan persentase 91\% dari hasil persentase tersebut dapat dikatakan bahwa materi pembelajaran sangat valid/dapat digunakan dengan kriteria perangkat pembelajaran $>85,01 \%$

e. hasil validasi materi pembelajaran menunjukkan bahwa hasil yang didapatkan dari validator I memperoleh total skor sebesar 40 dengan persentase $91 \%$. Validator II memperoleh total skor sebesar 44 dengan persentase $100 \%$. Kedua skor tersebut di total berjumlah 84 dengan rata-rata 42 dengan persentase 95\% dari hasil presentase tersebut 
dapat dikatakan bahwa materi pembelajaran sangat valid/dapat digunakan dengan kriteria perangkat pembelajaran $>85,01 \%$

2. Rekap hasil Validasi Perangkat Pembelajaran

Tabel 1. Rekapitulasi Hasil Validasi Perangkat Pembelajaran

\begin{tabular}{llllll}
\hline No & \multicolumn{1}{c}{ Jenis Perangkat } & \multicolumn{2}{c}{ Penilaian } & Rata-rata & Kategori \\
& & Validator I & Validator II & & \\
\hline 1 & Silabus & $94 \%$ & $100 \%$ & $97 \%$ & Sangat valid \\
2 & $\begin{array}{l}\text { Rencana Pelaksanaan } \\
\text { Pembelajaran (RPP) }\end{array}$ & $95 \%$ & $96 \%$ & $96 \%$ & Sangat valid \\
3 & $\begin{array}{l}\text { Materi Pembelajaran } \\
4\end{array}$ & $90 \%$ & $100 \%$ & $95 \%$ & Sangat valid \\
& $\begin{array}{l}\text { Lembar Kerja Peserta } \\
\text { Didik (LKPD) }\end{array}$ & $89 \%$ & $94 \%$ & $91 \%$ & Sangat valid \\
& $\begin{array}{l}\text { Tes Hasil Belajar (THB) } \\
\text { Tes }\end{array}$ & $91 \%$ & $100 \%$ & $95 \%$ & Sangat valid \\
\hline
\end{tabular}

Perangkat pembelajaran yang di berikan kepada validator telah dilakukan revisi selanjutnya akan di uji cobakan di SDN Tunjung Mekar Kalitengah Lamongan di kelas IV. Kepraktisan Pembelajaran Terpadu Tipe Shared Berbasis Saintifik, Sesuai dengan hasil penelitian Rosidi (2015) pengembangan perangkat pembelajaran IPA terpadu merupakan perangkat pembelajaran yang layak untuk digunakan dalam pembelajaran. Karena dalam pembelajaran terpadu memberikan keuntungan bagi guru karena dengan pembelajaran terpadu maka guru lebih dapat menghemat waktu dalam menyusun persiapan mengajar. Selain itu, pembelajaran terpadu menjebatani pengetahuan awal siswa menuju ke pengetahuan yang lebih luas.

3. Kepraktisan Pembelajaran terpadu Tipe Shared Berbasis Saintifik

a. Keterlaksanaan RPP ( Rencana Pelaksanaan Pembelajaran)

Nilai rata-rata keterlaksanaan RPP kelas Eksperimen pada peretemuan I memperoleh skor rata-rata 3.71 dengan kategori terlaksana sangat baik, pada pertemuan ke II memperoleh skor rata-rata 3.88 sehingga berada dalam ketegori terlaksana sangat baik. Hasil diatas menunjukkan bahwa pelaksanaan pembelajaran dapat terlaksana dengan sangat baik sesuai dengan rancangan yang telah dibuat oleh peneliti dan dapat dinyatakan praktis atau mudah digunakan oleh penguna.

b. Angket Respon Siswa Terhadap Pelaksanaan Pembelajaran

Analisis pada respon siswa terhadap perangkat pembelajaran terpadu tipe shared berbasis saintifik diperoleh respon sebesar 96,6\% yang menandakan bahwa respon siswa dalam ketegori sangat baik, namun ada beberapa respon siswa yang kurang baik dengan persentase 7,62\%. Namun secara keseluruhan dapat disimpulkan bahwa siswa menunjukkan respon yang positif dalam pelaksanaan pembelajaran dan siswa merasa senang dan tertarik terhadap perangkat pembelajaran yang dikembangkan.

4. Aktivitas Siswa

Aktivitas siswa selama proses pembelajaran dengan menggunakan perangkat pembelajaran terpadu tipe shared berbasis saintifik pada pertemuan 1 memperoleh persentase sebesar 81,2\% dengan kategori aktif, pada peretemuan 2 memperoleh persentase sebesar $82,2 \%$ dengan ketegori aktif. Secara keseluruhan proses pembelajaran 
pada pertemuan 1 dan 2 terlihat siswa aktif dalam proses pembelajaran sesuai dengan data yang diperoleh dari hasil pengamatan dua observer. Hal itu relevan dengan teori pembelajaran yang dikembangkan oleh Albert Bandura yang menekankan pada proses belajar melalui pengalaman atau pengamatan. Apalagi teori pembelajaran yang dikembangkan oleh Bandura, memang menekankan pada masalah perilaku atau pemodelan. (Dewi Ike: 2017).

5. Keefektifan Perangkat Pembelajaran

Hasil kelas kontrol saat pretest mendapatkan skor rata-rata sebesar 50,9\% dari jumlah siswa 26 hanya terdapat 1 siswa yang nilainya mencapai KKM, sedangkan untuk posttest di kelas kontrol mendapatkan skor rata-rata 71,9\% dari jumlah siswa di kelas 26 terdapat terdapat 11 siswa yang tuntas dan mencapai KKM. Rata-rata kelas kontrol saat posttest $<75$ sehingga dapat disimpulkan bahwa ketuntasan kelas kontrol kurang.

Hasil kelas eksperimen saat pretest mendapatkan skor rata-rata sebesar 53,4\% dari jumlah siswa 26 hanya terdapat 3 siswa yang nilainya mencapai KKM, sedangkan untuk posttest di kelas eksperimen mendapatkan skor rata-rata $80,1 \%$ dari jumlah siswa di kelas 26 terdapat 1 siswa yang tidak tuntas. Rata-rata kelas eksperimen mencapai $\geq 75$ sehingga dapat disimpulkan bahwa ketuntasan kelas eksprimen baik. Sejalan dengan penelitian Susilowati (2017) bahwa hasil belajar siswa meningkat dengan menggunakan perangkat pembelajaran terpadu Tipe Shared berbasis kegiatan Ekonomi Kreatif yang telah dikembangkan, sehingga perangkat pembelajaran dapat diterapkan di Sekolah Dasar, namun tetap memerlukan penyesuaian dengan situasi dan kondisi di sekolah.

6. Hasil uji

a. Uji Normalitas

Untuk mengetahui data berdistribusi normal jika signifikansi $>0,05$ maka data akan dinyatakan diterima apabila data signifikansi $<0,05$ maka data dinyatakan tidak diterima.

Tabel 2. Hasil uji Normalitas Pretest

\begin{tabular}{llrr}
\hline \multicolumn{3}{c}{ One-Sample Kolmogorov-Smirnov Test } & \\
& & Pretest Eksperimen & Pretest Kontrol \\
\hline $\mathrm{N}$ & & 26 & 26 \\
Normal & Mean & 51.77 & 50.92 \\
Parameters & Std. & 6.907 & 7.255 \\
& Deviation & & \\
Most Extreme & Absolute & .144 & .174 \\
Differences & Positive & .144 & .174 \\
& Negative & -.115 & -.109 \\
Kolmogorov-Smirnov Z & .736 & .889 \\
Asymp. Sig. (2-tailed) & .650 & .408 \\
\hline
\end{tabular}


Tabel 3. Hasil uji Normalitas Posttest

\begin{tabular}{|c|c|c|c|}
\hline \multicolumn{4}{|c|}{ One-Sample Kolmogorov-Smirnov Test } \\
\hline \multicolumn{2}{|l|}{$\mathrm{N}$} & 26 & 26 \\
\hline Normal & Mean & 80.12 & 71.92 \\
\hline \multirow[t]{2}{*}{ Parameters $^{a}$} & Std. & 3.659 & 3.815 \\
\hline & Deviation & & \\
\hline Most Extreme & Absolute & 218 & 207 \\
\hline \multirow[t]{2}{*}{ Differences } & Positive & .218 & .172 \\
\hline & Negative & -.164 & -.207 \\
\hline \multicolumn{2}{|c|}{ Kolmogorov-Smirnov Z } & 1.114 & 1.055 \\
\hline \multicolumn{2}{|c|}{ Asymp. Sig. (2-tailed) } & .167 & .216 \\
\hline
\end{tabular}

a. Test distribution is Normal.

Dari data diatas dapat disimpulkan bahwa kedua kelompok data tersebut memiliki sig > 0,05 dan berdistribusi normal.

b. Uji Homogenitas

Untuk mengetahui data diasumsikan sama jika signifikansi $>0,05$ maka data akan dinyatakan diterima apabila data signifikansi $<0,05$ maka data dinyatakan tidak diterima.

Tabel 4. Hasil Uji Homogenitas Pretest

\begin{tabular}{rrrr}
\hline Levene Statistic & df1 & df2 & Sig. \\
.021 & 1 & 50 & .886 \\
\hline
\end{tabular}

Tabel 5. Hasil Uji Homogenitas Posttest

\begin{tabular}{rrrr}
\hline Levene Statistic & df1 & df2 & Sig. \\
.128 & 1 & 50 & .722 \\
\hline
\end{tabular}

Dari data diatas dapat disimpulkan bahwa nilai signifikasi 0,886 $>0,05$ dan 0,722 > 0,05 maka varian dapat nyatakan homogen.

c. Uji t-Test

Untuk menguji perbedaan tes hasil belajar pretest di kelas ekperimen dan kontrol menggunakan Independent Samples Test.

Tabel 6. Hasil pree test.

t-test for Equality of Means

95\% Confidence Interval of the Difference

\begin{tabular}{lcrccr} 
& $\mathrm{T}$ & Df & $\begin{array}{c}\text { Sig. }(2- \\
\text { tailed) }\end{array}$ & Lower & \multicolumn{2}{c}{ Upper } \\
\cline { 2 - 6 } & .431 & 50 & .669 & -3.100 & 4.792 \\
$\begin{array}{l}\text { Equal variances } \\
\text { assumed }\end{array}$ & .431 & 49.880 & .669 & -3.100 & 4.792 \\
$\begin{array}{l}\text { Equal variances } \\
\text { not assumed }\end{array}$ & & & & & \\
\hline
\end{tabular}

Hasil di atas dapat diketahui bahwa t-test $\mathrm{t}$ mengasumsikan kedua kelas sama 0,431 dengan probaility signifikasinya sebesar 0,669 dengan artian >0,05 maka tidak ada perbedaan kemampuan awal untuk kelas kontrol dan kelas eksperimen. 
Tabel 7. Hasil Uji t Posttest

\begin{tabular}{llrrrrr}
\hline & & \multicolumn{2}{c}{$\begin{array}{c}\text { t-test for Equality of Means } \\
\mathrm{T}\end{array}$} & $\mathrm{df}$ & Sig. (2-tailed) & \multicolumn{2}{c}{$\begin{array}{c}\text { 95\% Confidence Interval of } \\
\text { the Difference }\end{array}$} \\
\hline Postest & $\begin{array}{l}\text { Equal variances } \\
\text { assumed }\end{array}$ & 7.903 & 50 & .000 & 6.110 & Upper \\
\hline $\begin{array}{l}\text { Equal variances } \\
\text { not assumed }\end{array}$ & 7.903 & 49.913 & .000 & 6.110 & 10.274 \\
\end{tabular}

Dari hasil di atas dapat diketahui dari angka T yang mengasumsi kedua kelas sama adalah 7,903 dengan signifikasinya sebesar 0,000. Angka signifikasi di bawah $<0,05$ dapat diartikan bahwa ada perbedaan nilai posttest di kelas eksperimen dan kontrol. Sehingga dapat disimpulkan terdapat pengaruh antara penggunaan perangkat pembelajaran terpadu tipe shared berbasis saintifik dalam meningkatkan hasil belajar siswa kelas IV di SDN Tunjung Mekar.

\section{Kesimpulan}

Berdasarkan hasil penelitian yang telah dilaksanakan, pengembangan perangkat pembelajaran yang dilakukan pada penelitian ini. Pertama, hasil validitas perangkat pembelajaran yang terdiri dari silabus, RPP, materi ajar, lembar kerja peserta didik, serta tes hasil belajar telah dinyatakan layak dan dapat digunakan. Kedua, kepraktisan perangkat pembelajaran dari hasil data keterlaksanaan serta respon siswa. keterlaksanaan pembelajaran pada pertemuan 1 dan 2 terlaksana dengan baik dan ada peningkatan pengelolaan pembelajaran yang dilaksanakan oleh guru serta respon siswa selama pembelajaran mendapatkan respon baik dari siswa. Ketiga, peningkatan hasil belajar siswa ditunjukkan melalui hasil pretest dan posttest yang menunjukkan bahwa kelas eksperimen yang menggunakan perangkat pembelajaran terpadu tipe shared berbasis saintifik lebih tinggi dibandingkan dengan kelas kontrol yang yang tidak menggunakan perangkat pembelajaran terpadu tipe shared berbasis saintifik. Dengan demikian, perangkat pembelajaran terpadu tipe shared berbasis saintifik dinyatakan efektif dan dapat meningkatkan hasil belajar siswa. Pada penelitian pengembangan ini hanya pada tahap implementasi. Perangkat pembelajaran yang dihasilkan, digunakan serta dimanfaatkan oleh guru dalam pembelajaran di kelas.

\section{Daftar Pustaka}

Anitah, Sri. (2003). Pembelajaran Terpadu Implementasi, Implementasi Paradigma Konstruktivistik dalam Rangka Pengembangan Kecerdasan Ganda. Surakarta : Sebelas Maret University Press.

Atsnan, M. F., (2013), Penerapan Pendekatan Scientific Dalam Pembelajaran Matematika SMP Kelas VII Materi Bilangan (Pecahan), Jurnal Nuansa Kependidikan, 4 (1) : 1 - 8.

Daryanto, (2014). Pembelajaran Tematik, Terpadu, Terintergrasi (Kurikulum 2013). Jogjakarta: Gava Media.

Dewi dkk. (2013). Pengembangan Perangkat Pembelajaran Ipa Terpadu dengan Setting Inkuiri Terbimbing untuk Meningkatkan Pemahaman Konsep dan Kinerja Ilmiah Siswa. eJournal Program Pascasarjana Universitas Pendidikan Ganesha Program Studi IPA. Vol. 3. 
Dewi, Ike. (2017). Pengembangan Perangkat Pembelajaran Terpadu Tipe Webbed Fokus IPA dengan Tema "Masyarakat Taneyan Lanjhang" Pada Sekolah Dasar di Kabupaten Sumenep. Jurnal Review Pendidikan Dasar: Jurnal Kajian Pendidikan dan Hasil Penelitian. Vol 3 , no 1 .

Dick, W. and Carey, L. (1985). The Systematic Design of Instruction (2nd Ed). Glecview, Illionis: Scot, Foresman and Company.

Febriyanto, Budi dkk.(2020). Model Pembelajaran Kontekstual Berbantuan Media Puzzle Untuk Menıngkatkan Hasıl Belajar Siswa. Jurnal Elementaria Edukasia. Vol 3, no 2.

Fogarty, Robin. (1991). The Mindfull Schools: How to Integrate The Curricula. Palatine Ilionis: IRI/Skylight Publishing.Inc.

Majid, Abdul. (2014). Strategi Pembelajaran. Bandung: PT Remaja Rosdakarya.

Permendikbud. (2016) Peraturan Menteri Pendidikan dan Kebudayaan Republik Indonesia No. 22 Tahun 2016 Tentang Standar Proses Pendidikan Dasar dan Menengah.

Prabowo, (2000). Pembelajaran Fisika dengan Pendekatan Terpadu dalam Menghadapi Perkembangan IPTEK Millenium III. Makalah disampaikan pada seminar lokakarya Jurusan Fisika FMIPA Universitas Negeri Surabaya bekerjasama dengan Himpunan Fisika Indonesia (HFI).

Prasrihamni, Mega dkk. (2020). Pengembangan Bahan Ajar Membaca Permulaan Dalam Pembelajaran Tematık Dengan Model Vark di Kelas I Sekolah Dasar. Jurnal Elementaria Edukasia. Vol 3, no 2.

Rosidi, Irsad. (2015). Pengembangan Perangkat Pembelajaran IPA Terpadu Tipe Integrated untuk Mengetahui Ketuntasan Belajar IPA Siswa SMP Pada Topik Pengelolaan Lingkungan. Jurnal Pena Sains Vol. 2, No. 1.

Sugiyono. (2011). Metode Penelitian Kuantitatif, Kualitatif dan RED. Bandung: Alfabeta.

Susilowati, Bekti. (2017). Pengembangan Perangkat Pembelajaran Terpadu Tipe Shared Berbasıs Kegıatan Ekonomı Kreatıf untuk Siswa Kelas IV Sekolah Dasar. Jurnal Review Pendidikan Dasar: Jurnal Kajian Pendidikan dan Hasil Penelitian. Vol 3, no 7.

Trianto, (2012). Model Pembelajaran Terpadu. Jakarta: PT Bumi Aksara.

Utami dkk. 2019. Pengembangan Pembelajaran IPBA dengan Pendekatan Saintifik. Wahana Matematika dan Sains: Jurnal Matematika Sains dan Pembelajarannya. Vol 13, no 2.

Wiyono, Surahman Oki. (2013). Pengembangan Perangkat Pembelajaran IPA Terpadu Tipe Shared Pada Materi Molekul dan Perubahan Energi dalam Metabolisme Tumbuhan Hijau Kelas VIII. Jurnal Sains E-Pensa. Vol 01, no 01.

Yunita, Herina dkk. (2019). Meningkatkan Kemampuan Berpikir Kritis Melalui Pendekatan Saintifik. Jurnal Obsesi: Pendidikan Anak Usia Dini. Vol. 3, Issue 2. 